\title{
Purification and characterization of laccase from Pleurotus tuber-regium and its application in dye decolourization
}

\author{
Comfort O. Bamigboye *, Julius K. Oloke, Bidemi Olaogun, Zainab Alabi, \\ Damilola Ogunbiyi, Alice Ogundare, Dayo Akinloye
}

Microbiology Unit, Department of Pure and Applied Biology, Ladoke Akintola University of Technology, Ogbomoso, Nigeria

\begin{abstract}
Pleurotus tuber-regium is a unique sclerotium-forming white rot fungus. It is edible and has medicinal value and a high potentials of application in various industries. However, to date, there is no information on the production of laccase by this fungus, the purification and determination of decolourization potential of laccase have also not been reported. In this study, purification of laccase from $P$. tuber-regium is demonstrated for the first time. Laccase was purified from the submerged culture of $P$. tuber-regium using ammonium sulfate precipitation, ion-exchange chromatography and gel filtration chromatography. The molecular weight of laccase was determined using sodium dodecyl sulfate polyacrylamide gel electrophoresis. The purified laccase was characterized to determine its optimum $\mathrm{pH}$ and temperature, substrate specificity, Michaelis-Menten constant, and inhibitors. The decolourization potential of the crude laccase was evaluated using Congo red, trypan blue, textile dyes and textile effluent. The purified laccase had a molecular weight of $52 \mathrm{kDa}$, optimum $\mathrm{pH}$ and temperature were 4 and $60^{\circ} \mathrm{C}$, respectively. The best substrate for laccase was found to be 2,2'-azino-bis (3-ethylbenzothiazoline-6-sulfonate), with a Michaelis-Menten constant $\left(K_{m}\right)$ of $7.82 \mu \mathrm{M}$. Laccase activity was mildly inhibited by ethylenediamine tetraacetic acid (EDTA) and L-cysteine, but strongly inhibited by sodium azide. The activity of the purified laccase was enhanced by more than two fold by $\mathrm{Na}^{+}, \mathrm{Ca}^{2+}$ and $\mathrm{Ba}^{2+}$, and slightly enhanced by $\mathrm{Hg}^{2+}$ and $\mathrm{Mn}^{2+}$. The crude laccase was able to efficiently decolourize trypan blue and Congo red dyes and red and blue textile dyes. Notably, on solid agar, trypan blue was completely degraded by intracellular laccase.
\end{abstract}

Key words: fungal laccase; textile dye biodegradation; decolourization of trypan blue dye; Pleurotus tuber-regium; medicinal mushroom

\section{Introduction}

Laccase is a polyphenol oxidase containing copper (Patel, 2013) and belonging to the family of the blue multicopper oxidases. It is produced by the white-rot fungi (Othman et al., 2014; Martani et al., 2017; Agrawal et al., 2018) and some actinomycetes (Niladevi and Prema, 2008; Yadav et al., 2019), insects including termites (Coptotermes formosanus) (Geng et al., 2018) and silkworm (Bombyx mori) (Yatsu and Asano, 2009), and some plant species (such as Acer pseudoplatanus and Populus euramericana) (Cai et al., 2006; Prajapati and Minocherherhomji, 2018). Certain bacteria including
Escherichia coli, Pseudomonas putida, Bacillus sp, Streptomyces sp and Azospirillum sp. (Kiiskinen et al., 2004) are also known to produce this enzyme. Laccases were first obtained from a fungal source in 1896 (Kunamneni et al., 2007). Interestingly, fungal laccases have both degradative and synthetic properties unlike the laccases produced by plants, bacteria and insects (Sharma et al., 2018). These functions of laccases have been utilized in the synthesis of aromatic aldehydes, indamine dye, totarol, and 3,4-dihydro-7,8-dihydroxy-2H-dibenzofuran-1-ones from Trametes versicolor, Coriolus hirsutus, Trametes pubescens and Agaricus bisporus, res-

\footnotetext{
* Corresponding author: Microbiology Unit, Department of Pure and Applied Biology, Ladoke Akintola University of Technology, P.M.B. 4000, Ogbomoso, Nigeria; e-mail: coadegunlola@lautech.edu.ng
} 
pectively (Baker et al., 1996; Fritz-Langhals and Kunath, 1998; Ncanana et al., 2007). These uses of fungal laccases have been attributed to their higher redox compared to laccases obtained from other sources (Sharma et al., 2018), and hence their application in the synthesis of pharmaceutically important compounds.

In nature, laccase is involved in the production of melanin which fights against environmental stresses, while some phytopathogenic fungi use laccase as a lignin-degrading enzyme to penetrate the lignotubers (Henson et al., 1999; Sharma et al., 2018). Laccases and the microorganisms that produce them play important roles in the bioremediation of xenobiotics, industrial pollutants and aromatic substances (Prajapati and Minocheherhomji, 2018). Other practical applications of laccase include detoxification of waste water, finishing of denim fabrics, bleaching of textile dyes, delignification of pulp, and transformation of steroids and antibiotics (Sheikh et al., 2012; Sharma et al., 2015).

Pleurotus tuber-regium (Fr.) Singer is a white-rot fungus widely distributed in tropical countries and regions including equatorial Africa, Asia, Northern Australia, and South Pacific (Bamigboye et al., 2016). It prefers a warm and humid environment for growth (Vilgalys, 1996; Bamigboye et al., 2019). The fungus $P$. tuber-regium is primarily saprotrophic, found on dead or decaying wood, with its enzymes involved in the breakdown of the darker-colored lignin, leaving behind white stringy wood debris. Its basidiocarps develop from underground sclerotia, and emerge from the soil when the atmospheric conditions are favorable (Okhuoya and Okogbo, 1990). Although a number of studies are available on the laccases obtained from white-rot fungi and their applications (Nagai et al., 2003; Ramírez-Cavazos et al., 2014; Wang et al., 2018; Pandey et al., 2018), there is only one preliminary investigation on the ligninolytic enzymes from $P$. tuber-regium reported so far (Isikhuemhen and Nerud, 1999). Laccase produced by P. tuber-regium has been poorly studied, and the characterization as well as purification of laccase from this fungus has received no attention. However, characterization and purification of laccase would significantly improve its applicability in medical and industrial areas, since this enzyme functions efficiently in the production of some pharmaceutical compounds such as Vinblastine and actinocin (Kunamneni et al., 2008), which shall boost the overall income of the mushroom breeders. To our knowledge, there has been no study focusing on the purification and characterization of laccase from $P$. tuber-regium. This fungus forms sclerotia that can be preserved for months and thus may be easily available for application in bioremediation. This study was therefore aimed at characterizing and purifying the laccase enzyme from $P$. tuber-regium - Pt30 and exploring its application potential in dye decolorization.

\section{Materials and methods}

\section{Organism collection and maintenance}

The mycelium of the strain P. tuber-regium, - Pt30 (NCBI accession number KP325383) was obtained from the Microbiology Unit of the Department of Pure and Applied Biology, Ladoke Akintola University of Technology, Ogbomoso, Nigeria. The organism was maintained on potato dextrose agar (PDA) plates at $25^{\circ} \mathrm{C}$ and subcultured for the research demands.

\section{Laccase plate screening assay}

Laccase plate screening assay was performed following the method of Kiiskinen et al. (2004) with slight modifications. Three types of medium were prepared for detecting laccase production: PDA with $0.01 \%$ guaiacol, PDA with $0.5 \%(\mathrm{w} / \mathrm{v})$ tannic acid, and PDA with $1 \mathrm{mM}$ (2,2'-azino-bis (3-ethybenzothiazoline-6-sulfonic acid) (ABTS). The media were autoclaved at $121^{\circ} \mathrm{C}$ for $15 \mathrm{~min}$, allowed to cool, and then poured into $90 \mathrm{~mm}$ Petri dishes. Precisely, mycelia agar discs measuring $5 \mathrm{~mm}$ were aseptically cut from the previously prepared PDA plates (using a glass Pasteur pipette) containing exponentially growing mycelia of $P$. tuber-regium - Pt30. Fusarium sp. was used as a negative control. The screening media were each inoculated at the center with a $5 \mathrm{~mm}$ mycelia agar disc, and incubated at $30^{\circ} \mathrm{C}$ and inspected daily for 7 days.

\section{Culture conditions and laccase assay}

Six mycelia plugs (5 $\mathrm{mm}$ in diameter) of $P$. tuber-regium - Pt30 were inoculated into a $250 \mathrm{ml}$ conical flask containing $100 \mathrm{ml}$ of the basal medium. The basal medium contained $18 \mathrm{~g} / \mathrm{l}$ glucose, $3.8 \mathrm{~g} / \mathrm{l}$ yeast extract, $1 \mathrm{~g} / \mathrm{l}$ $\mathrm{KH}_{2} \mathrm{PO}_{4}$ and $0.06 \mathrm{~g} / 1 \mathrm{MgSO}_{4} \cdot 7 \mathrm{H}_{2} \mathrm{O}$. The culture was incubated at $30^{\circ} \mathrm{C}$ for 10 days. Laccase activity was determined according to the modified method of $\mathrm{Lu}$ et al. (2007). At the final concentration, the reaction mixture 
contained $1.95 \mathrm{ml}$ of $0.1 \mathrm{M}$ citrate - phosphate buffer (pH 3.4), $1 \mathrm{ml}$ of $0.1 \mathrm{M} \mathrm{ABTS}$, and $50 \mu \mathrm{l}$ of the crude enzyme in a final volume of $3 \mathrm{ml}$. The mixture was incubated for $3 \mathrm{~min}$ at $25^{\circ} \mathrm{C}$. Oxidation of ABTS was detected by monitoring the change in absorbance at $420 \mathrm{~nm}$. A unit of the activity of laccase is defined as the amount of enzyme that oxidizes $1 \mu \mathrm{mol}$ of ABTS per minute at $25^{\circ} \mathrm{C}$. The protein concentration was determined using the method of Bradford (1976) using bovine serum albumin was used as a standard.

\section{Purification of laccase}

After 10 days, the cultures were harvested by filtration and centrifugation at $4000 \mathrm{rpm}$ for $25 \mathrm{~min}$. The obtained supernatant was saturated with $80 \%$ ammonium sulfate by adding solid ammonium sulfate over a period of $1 \mathrm{~h}$ with occasional stirring and leaving the solution for $12 \mathrm{~h}$ on ice. The resulting precipitate was collected by centrifugation at $4000 \mathrm{rpm}$ for $30 \mathrm{~min}$ at $10^{\circ} \mathrm{C}$. Next, dialysis tubing was pre-treated by boiling in $0.01 \mathrm{M}$ ethylenediamine tetraacetic acid (EDTA) for $30 \mathrm{~min}$ followed by another pre-treatment in distilled water $\left(\right.$ at $100^{\circ} \mathrm{C}$ ) twice, for 30 min each. The precipitate resulting from ammonium sulfate fractionation was dialyzed for $18 \mathrm{~h}$ against 31 of $20 \mathrm{mM}$ sodium phosphate buffer $(\mathrm{pH} 6.5)$ at $28^{\circ} \mathrm{C}$.

CM-Sephadex $\mathrm{C} 50$ cation exchanger (Sigma, USA) was pre-treated by first swelling $20 \mathrm{~g}$ of resin in 11 of distilled water for $24 \mathrm{~h}$. The resin was then washed with 15 volumes of $0.5 \mathrm{M} \mathrm{NaOH}$ for $30 \mathrm{~min}$ followed by a series of stirring and decantation process until effluent attained $\mathrm{pH} 8$. The effluent was later washed with 15 volumes of $0.5 \mathrm{M}$ $\mathrm{HCl}$ followed by continuous washing with distilled water until it reached $\mathrm{pH} 7$. A column $(2.5 \times 40 \mathrm{~cm})$ of DEAECellulose (Sigma, USA) was packed and equilibrated with $20 \mathrm{mM}$ sodium phosphate buffer ( $\mathrm{pH}$ 6.5). The dialyzed protein obtained from the preceding step was then layered on the column. The column was first washed with $20 \mathrm{mM}$ sodium phosphate buffer ( $\mathrm{pH}$ 6.5) to remove the unbound proteins, followed by elution with a $400 \mathrm{ml}$ linear gradient of $0.1 \mathrm{M} \mathrm{NaCl}$ in $20 \mathrm{mM}$ sodium phosphate buffer (pH 6.5). Fractions of $3 \mathrm{ml}$ were collected from the column that was maintained at a flow rate of $30 \mathrm{ml} / \mathrm{h}$ $(0.5 \mathrm{ml} / \mathrm{min})$. The concentration of particular protein fractions was monitored spectrophotometrically using the method of Bradford (1976). The fractions were assayed for laccase activity as earlier described, and the fractions showing high laccase activity were pooled.

\section{Sodium dodecyl sulfate-polyacrylamide gel electrophoresis}

The protein sample was prepared by adding $0.2 \mathrm{ml}$ of the sample buffer (containing $0.01 \mathrm{M}$ sodium phosphate buffer ( $\mathrm{pH} 7.2$ ), $1 \mathrm{~g}$ sodium dodecyl sulphate (SDS) and $1 \mathrm{ml}$ of 2-mercaptoethanol to $0.1 \mathrm{ml}$ of the enzyme preparation, heated in a boiling water bath for $2 \mathrm{~min}$, and then cooled. A drop of glycerol was added to the sample, and $0.2 \mathrm{ml}$ of the sample was applied on the gel. Electrophoresis was run at $8 \mathrm{~mA}$ until the marker dye was about $1 \mathrm{~cm}$ from the anodic end of the gel. After electrophoresis the gels were removed by squirting water between the gel and the glass wall using a syringe.

\section{Determination of the kinetic parameters of $P$. tuber-regium laccase}

The kinetic parameters $\left(V_{\max }\right.$ and $K_{m}$ ) of the enzyme were measured according to the modified method of Zhang et al. (2010). The $K_{m}$ of ABTS was calculated by varying its concentration between 0.1 and $1 \mathrm{mM}$. The parameters were determined from the double-reciprocal plot of Lineweaver and Burk (1934). Lines through the points were drawn using the method of regression.

\section{Substrate specificity studies}

The substrate specificity of laccase was investigated by testing its activity towards structurally similar compounds which included catechol and guaiacol. The solutions of these two compounds $(1 \mathrm{mM})$ were prepared in $20 \mathrm{mM}$ sodium phosphate buffer ( $\mathrm{pH}$ 6.5). Enzyme activity was measured following the modified method of $\mathrm{Lu}$ et al. (2007). At the final concentration, the reaction mixture contained $0.1 \mathrm{M}$ citrate-phosphate buffer ( $\mathrm{pH} 3.4$ ), $1 \mathrm{mM}$ solution of the substrates and $50 \mu \mathrm{l}$ of the enzyme preparation in a final volume of $3 \mathrm{ml}$.

\section{Effect of temperature on laccase activity}

The activity of laccase was assayed at temperatures between 30 and $100^{\circ} \mathrm{C}$. The assay mixture was first incubated at the indicated temperature for $10 \mathrm{~min}$. The reaction was then initiated by adding $50 \mu$ of the enzyme $(1.12 \mathrm{mg} / \mathrm{ml})$ equilibrated at the same temperature.

\section{Effect of pH on laccase activity}

The effect of $\mathrm{pH}$ on laccase was studied by assaying the enzyme at different $\mathrm{pH}$ values using $5 \mathrm{mM}$ citrate buffer (pH range between 3.0 and 6.5) and $5 \mathrm{mM}$ phosphate ( $\mathrm{pH}$ range between 6.5 and 8.0). 


\section{Inhibition studies}

\section{Effects of metal chelating compounds}

The inhibitory effects of chelating compounds on laccase produced by $P$. tuber-regium - Pt30 were investigated by pre-incubating the purified enzyme solution $(1 \mathrm{ml})$ with the compounds $(1 \mathrm{ml})$ at $4{ }^{\circ} \mathrm{C}$ for $1 \mathrm{~h}$ before determining the residual laccase activity. The chelating compounds EDTA, sodium azide, and L-cysteine were used for this analysis at a final concentration of $10 \mathrm{mM}$.

\section{Effects of metal ions}

The effect of metal ions on laccase activity was determined using a method described by Kuddus et al. (2013). The salts $\mathrm{HgCl}_{2}, \mathrm{BaCl}_{2}, \mathrm{MnCl}_{2}, \mathrm{NaCl}$, and $\mathrm{KCl}$ were used for this analysis at a final concentration of $10 \mathrm{mM}$.

\section{Decolourization studies}

The effectiveness of $P$. tuber-regium - Pt30 in decolorizing Congo red and trypan blue dyes was investigated in both solid and liquid media (submerged fermentation). PDA was separately compounded with $0.02 \%$ of Congo red and trypan blue dyes, and then inoculated with $5 \mathrm{~mm}$ agar plug and incubated at $30^{\circ} \mathrm{C}$ for 10 days. For quantitative determination, two agar plugs of $P$. tuber-regium, measuring $5 \mathrm{~mm}$ in diameter, were inoculated into $100 \mathrm{ml}$ of minimal salt medium (MSM) containing $3.8 \mathrm{~g} / 1$ of yeast extract, $18 \mathrm{~g} / 1$ of glucose, $0.06 \mathrm{~g} / \mathrm{l}$ of $\mathrm{MgSO}_{4}$, and $0.01 \mathrm{~g} / 1$ of $\mathrm{KH}_{2} \mathrm{PO}_{4}$ and incubated for 4 days. The culture broth was then filtered with a Whatman No. 1 filter paper, and the crude laccase was used in decolorization of Congo red and trypan blue dyes. To further evaluate the potential of the fungus in the biodegradation of textile dyes, blue, royal blue, brown, and red textile dyes $(0.02 \%$ each) were compounded into MSM, and then inoculated with two $5 \mathrm{~mm}$ agar plugs of P. tuber-regium and incubated at $30^{\circ} \mathrm{C}$ for 15 days. Colour changes were visually monitored and also measured spectrophotometrically.

\section{Results}

\section{Plate screening assay}

Laccase-producing fungi are commonly detected through the development of brown, purple, or reddishbrown colour around the fungi mycelia when grown in a medium containing tannic acid, ABTS or guaiacol res-

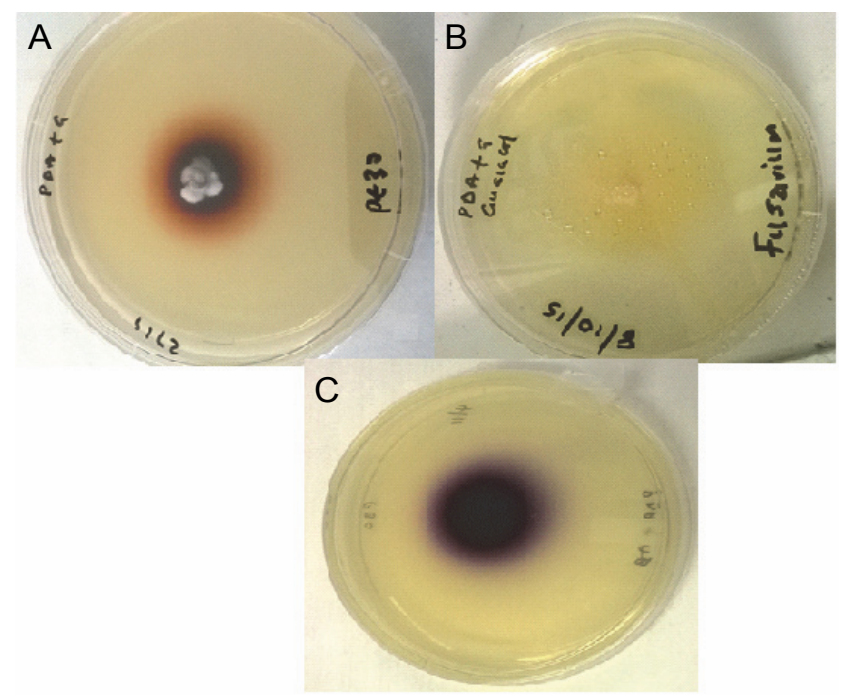

Fig. 1. Plate screening for the detection of laccase using selected indicators. A) The brownish zone around Pt30 mycelia on PDA plate containing guaiacol indicates laccase production B) Fusarium sp. (negative control - non-laccase producer) grown on PDA plate containing guaiacol with no colour production. C) PDA plate containing ABTS showing purplish colouration indicating production of laccase by $P$. tuber-regium - Pt30

pectively (Wang et al., 2018). This suggests that when laccase screening test is positive, the media changes from colorless to brown, purple or reddish-brown colored (if tannic acid, ABTS or guaiacol is present, respectively) due to the oxidation reactions catalyzed by laccase. In this study, during the initial analysis of laccase producing ability, the PDA plates used for growing the fungus $(P$. tuberregium), containing guaiacol and $\mathrm{ABTS}$, showed the development of brown and purple colors around the mycelia, respectively (Fig. 1). However, the PDA plates containing tannic acid used for the growth of $P$. tuber-regium mycelia, developed no color. Another fungal species used as negative control, Fusarium, which is a non-laccase producer, also showed no color production (Fig. 1).

\section{Laccase purification}

The crude laccase of $P$. tuber-regium - Pt30 was subjected to different purification steps, including ammonium sulfate precipitation, ion exchange and gel filtration, which have a marked influence on the enzyme activity. The specific activity and total protein content of the crude laccase were determined to be $0.43 \mu \mathrm{mol} \cdot \mathrm{mg}^{-1} \cdot \mathrm{ml}^{-1}$ and $150.38 \mathrm{mg}$, respectively (Table 1). Ammonium sulfate precipitation and ion-exchange chromatography increased the specific activity of laccase from 0.43 to 1.02 and 
Table 1. Summary of the purification of laccase from $P$. tuber-regium - Pt30

\begin{tabular}{l|c|c|c|c|c}
\hline \multicolumn{1}{c|}{$\begin{array}{c}\text { Purification } \\
\text { steps }\end{array}$} & $\begin{array}{c}\text { Total protein } \\
{[\mathrm{mg}]}\end{array}$ & $\begin{array}{c}\text { Total } \\
\text { laccase } \\
\text { activity }\end{array}$ & $\begin{array}{c}\text { Specific activity } \\
{[\mu \mathrm{mol} / \mathrm{mg} / \mathrm{ml}]}\end{array}$ & $\begin{array}{c}\text { Yield } \\
{[\%]}\end{array}$ & $\begin{array}{c}\text { Purification } \\
\text { fold }\end{array}$ \\
\hline Crude enzyme & 150.38 & 64.12 & 0.43 & 100 & 1 \\
\hline Ammonium sulfate precipitation & 54.10 & 55.19 & 1.02 & 85.97 & 2.37 \\
\hline CM-Sephadex ion exchange & 20.32 & 43.23 & 2.13 & 67.42 & 4.95 \\
\hline Bio-Gel P-100 gel filtration & 1.57 & 13.11 & 8.35 & 20.44 & 19.42 \\
\hline
\end{tabular}

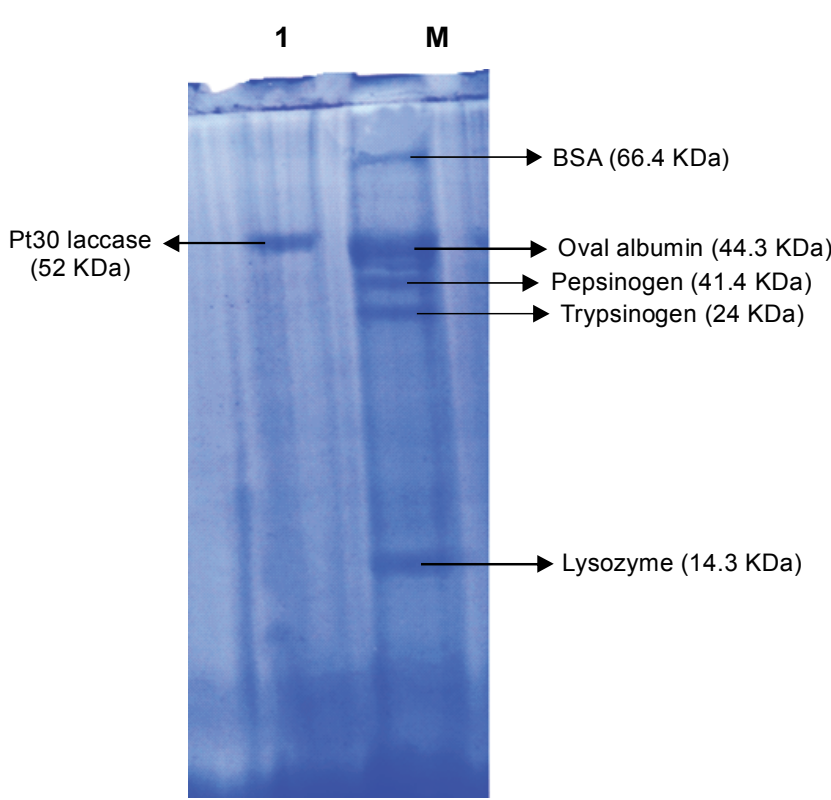

Fig. 2. SDS-PAGE analysis of laccase from P. tuber-regium-Pt30

$2.13 \mu \mathrm{mol} \cdot \mathrm{mg}^{-1} \cdot \mathrm{ml}^{-1}$ respectively with a total protein content of 54.10 and $20.32 \mathrm{mg}$ respectively (Table 1 ). In addition, gel filtration chromatography favorably increased the specific activity of the crude enzyme from 0.43 to $8.35 \mu \mathrm{mol} / \mathrm{mg} / \mathrm{ml}$ (Table 1 ). The SDS-PAGE analysis of the purified laccase showed a single band with a molecular weight of $52 \mathrm{kDa}$ (Fig. 2).

Effect of $\mathrm{pH}$ and temperature on the specific activity of the purified laccase of P. tuber-regium mutant Pt30

The evaluation of the effect of $\mathrm{pH}(3-8)$ on the activity of purified laccase showed that the optimum $\mathrm{pH}$ for the specific activity of laccase obtained from $P$. tuber-regium - Pt30 at $60^{\circ} \mathrm{C}$ was $4(20.5 \mathrm{U})$. In comparison with the other $\mathrm{pH}$ values tested, the laccase activity at $\mathrm{pH} 3,4.5$ and 5 was $0.278,1.94$ and $0.833 \mathrm{U}$, respectively. The enzyme showed no activity at the alkaline $\mathrm{pH}$ range which implies that the laccase from $P$. tuber-regium - Pt30 can function efficiently only at acidic pH (Fig. 3).

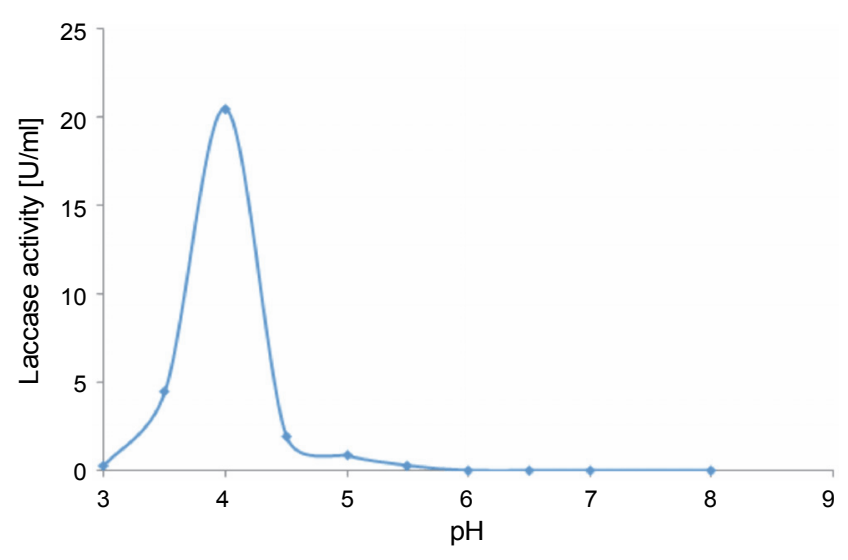

Fig. 3. Effect of $\mathrm{pH}$ on the activity of the laccase purified from the submerged fermentation media of $P$. tuber-regium mutant Pt30

The activity of the purified laccase of $P$. tuber-regium - Pt30 was at the peak at $60^{\circ} \mathrm{C}$. At 40,60 and $80^{\circ} \mathrm{C}$, the laccase activity was recorded to be $9.17,11.9$ and $7.5 \mathrm{U}$, respectively. This indicates that the laccase obtained from Pt30 mutant retains its activity only at a high temperature of $60^{\circ} \mathrm{C}$ (Fig. 4).

\section{Effect of metal ions and inhibitors on laccase activity}

The evaluation of the effect of metal ions showed that the chloride salts of potassium, sodium, calcium, barium, mercury and manganese at a concentration of $1.5 \mathrm{mM}$ had no inhibitory effect on the activity of the laccase purified from $P$. tuber-regium - Pt30 (Table 2). Interestingly, laccase activity was stimulated in the presence of these metals; for instance, when sodium, barium, or calcium was present in the assay mixture, laccase activity increased to 220,241 , and $208 \%$, respectively. This suggests that instead of inhibiting laccase, these chloride salts stimulated its activity by more than two fold (Table 2). Similarly, the chloride salts of mercury, manganese and potassium enhanced laccase activity up to 158.9 , 137.48 , and $103.45 \%$, respectively. 


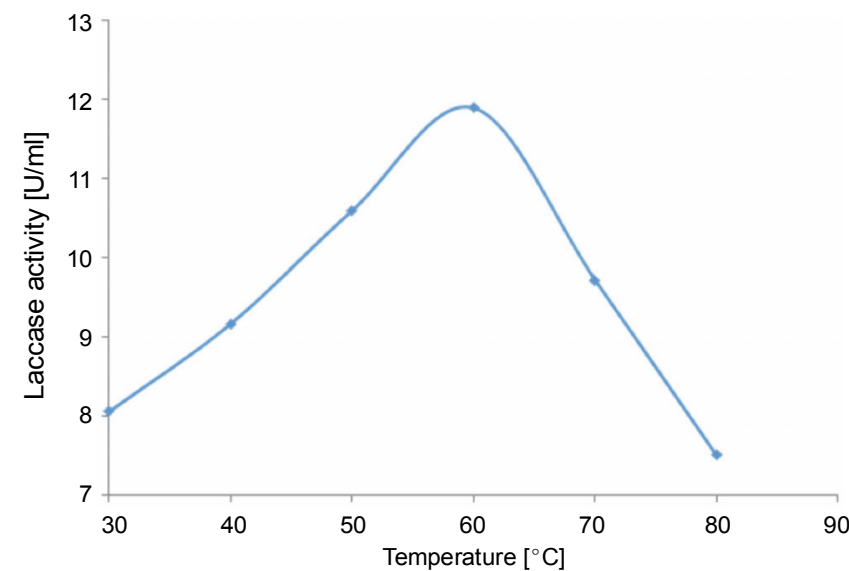

Fig. 4. Influence of temperature on the activity of laccase purified from the submerged culture of $P$. tuber-regium mutant Pt30 (optimum temperature $-60^{\circ} \mathrm{C}$ )

Table 2. Effect of chloride salts at a concentration of $10 \mathrm{mM}$ on the activity of purified laccase from P. tuber-regium - Pt30

\begin{tabular}{c|c}
\hline Chloride salts & $\begin{array}{c}\text { Residual activity } \\
\text { [\%] }\end{array}$ \\
\hline $\mathrm{KCl}$ & 103.45 \\
\hline $\mathrm{NaCl}$ & 220.39 \\
\hline $\mathrm{CaCl}_{2}$ & 208.4 \\
\hline $\mathrm{BaCl}_{2}$ & 241.4 \\
\hline $\mathrm{HgCl}_{2}$ & 158.9 \\
\hline $\mathrm{MnCl}_{2}$ & 137.48 \\
\hline
\end{tabular}

Among the tested inhibitors, sodium azide notably inhibited laccase activity leaving a residual activity of $18 \%$, but EDTA and L-cysteine exhibited only a mild inhibitory effect leaving a residual activity of 77 and $88 \%$, respectively (Fig. 5).

\section{Kinetics of laccase from P. tuber-regium mutant, Pt30}

The ability of laccase purified from the submerged culture of $P$. tuber-regium to oxidize different substrates (ABTS, catechol and guaiacol) was evaluated. $K_{m}$ and $V_{\max }$ were determined using different concentrations (from 0.1 to $1 \mathrm{mM}$ ) of the mentioned substrates. The Line-weaver - Burk plots showed that Pt30 laccase had a higher affinity for ABTS substrate than for the other substrates (Fig. 4) which was indicated by the low $K_{m}$ value. ABTS, catechol and guaiacol had a $K_{m}$ value of $7.82 \times 10^{-5}, 6.45 \times 10^{-5}$ and $32.39 \times 10^{-5} \mathrm{mM}$, respectively, and a $V_{\max }$ value of $2.9 \times 10^{-5}, 1.349 \times 10^{-5}$ and 12.5 $\times 10^{-5}$, respectively (Table 3 ). This high affinity of lac-

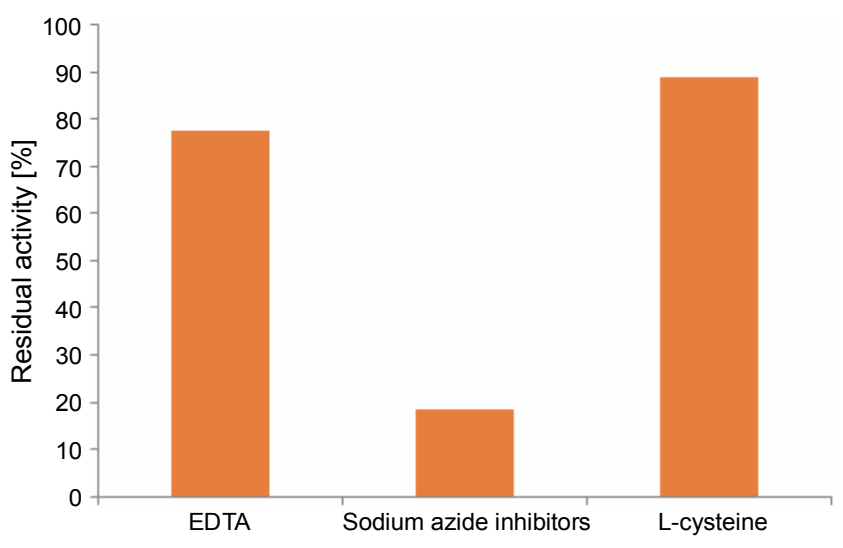

Fig. 5. Effect of inhibitors (at $10 \mathrm{mM}$ ) on the activity of the purified laccase of $P$. tuber-regium mutant Pt30

Table 3. Substrate specificity studies on purified laccase of $P$. tuber-regium - Pt30

\begin{tabular}{c|c|c}
\hline Substrate & $\begin{array}{c}K_{m} \\
{[\mathrm{mM}]}\end{array}$ & $\begin{array}{c}V_{\max } \\
{[\mathrm{mM}]}\end{array}$ \\
\hline ABTS & $7.82 \times 10^{-5}$ & $2.9 \times 10^{-5}$ \\
\hline Catechol & 6.456 & 1.349 \\
\hline Guaiacol & 32.3875 & 12.5 \\
\hline
\end{tabular}
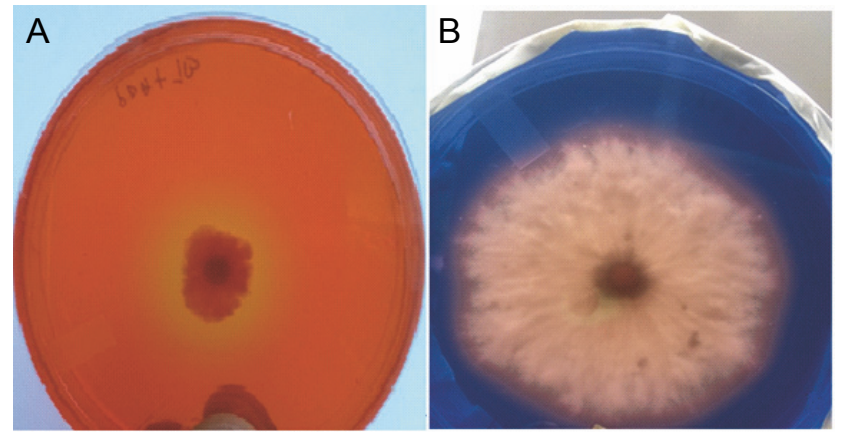

Fig. 6. PDA plates with fungal growth indicating: A) clear zone of decolorization of Congo red dye biosorbed by the mycelia of $P$. tuber-regium - Pt30 through secretion of laccase extracellularly, B) clear zone of decolorization of trypan blue dye around the mycelia of $\mathrm{Pt} 30$ and a complete metabolism or biodegradation of the trypan blue dye after 7 days via secretion of laccase intracellularly

case for ABTS implies that ABTS is a better substrate than catechol and guaiacol for the laccase understudy.

\section{Decolorization experiments}

The decolorization studies showed that $P$. tuber-regium - Pt30 was able to effectively decolourize Congo red and trypan blue dye in solid agar media (Fig. 6) and 


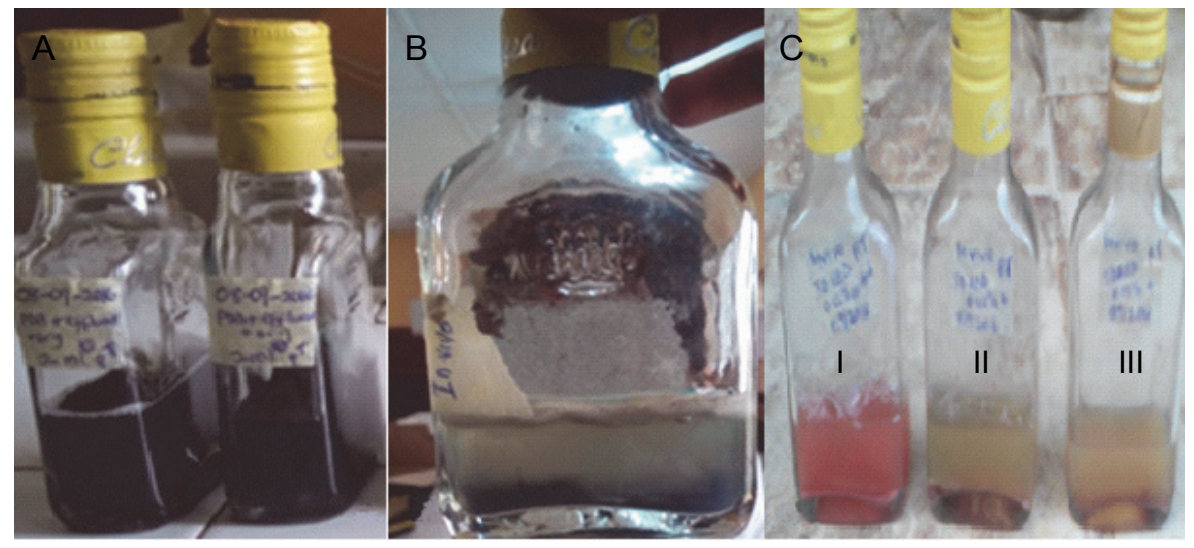

Fig. 7. Degradation of (A and B) blue textile dye (A - before degradation and B - after degradation) and $\mathrm{C}$ ) red textile dye by $P$. tuber-regium after 15 days of incubation in a liquid medium (I - control; II and III - experimental set ups showing dye degradation)

submerged fermentation media. In the latter, $P$. tuber-regium - Pt30 effectively decolourized trypan blue and Congo red dye by 65 , and $28.85 \%$, respectively. In addition, $P$. tuber-regium effectively decolourized 77,63 , 85 and $52 \%$ of blue, red, royal blue and brown textile dyes, respectively. The decolorization potential of laccase was visible by the reduction in the colour intensity of the dyes (Fig. 7).

\section{Discussion}

Laccases produced by many white rot fungi including; Cerrena unicolor (Wang et al., 2017), Lentinula edodes (Nagai et al., 2003), Pycnoporus sanguineus (RamírezCavazos et al., 2014), Trametes orientalis (Zheng et al., 2017), Trichoderma harzianum (El Monssef et al., 2016; Bagewadi et al., 2017), Pleurotus ostreatus (Othman et al., 2014; El-Batal et al., 2015), Pleurotus sajor-caju (Fokina et al., 2016), Pleurotus pulmonarius (Marques de Souza and Peralta, 2003; Behrens et al., 2017), Pleurotus sapidus (Schwienheer et al., 2015), Pleurotus eryngii (Loi et al., 2018), Pleurotus ferulae (Ding et al., 2014; Wang et al., 2015), and Pleurotus djamor (Salmones and Mata 2015) have been purified, characterized and studied in detail by many authors. However, laccase produced by $P$. tuber-regium has never been studied in detail, even though a previous study demonstrated the versatility of this fungus (Isikhuemhen and Nerud, 1999). Therefore, this study attempted to bridge the gap in the knowledge by purifying and characterizing the laccase from the submerged culture of $P$. tuber-regium, and evaluating its dye-decolorizing ability. The production of laccase by P. tuber-regium - Pt30 was confirmed by the development of purple or reddish-brown color when ABTS or guaiacol was included in the PDA media, respectively (Fig. 1). The fungal strain $P$. tuber-regium - Pt30 that was screened for laccase production tested positive in PDA-ABTS and PDA-guaiacol media, but negative in PDA-tannic acid media. The reason for lack of colour development in the PDA-tannic acid media was not clear, but a similar observation was made by Kiiskinen et al. (2004) with a conclusion that tannic acid is less specific in screening for laccase-producing fungi and could give false positive or false negative results. However, the other two colour indicators (ABTS and guaiacol) have been used in several studies and found to give consistent results (Kiiskinen et al., 2004; Jebapariya and Gnanadoss, 2014). This suggests that it is more reliable to use ABTS and guaiacol when screening for laccase producers.

In this study, the enzyme laccase was purified using ammonium sulfate precipitation, ion-exchange chromatography, and affinity chromatography. The specific activity of the purified enzyme was 8.35 , and the yield of the enzyme was $20.44 \%$ (Table 1 ). The purified laccase of P. tuber-regium - Pt30 was found to have the optimum activity at $\mathrm{pH} 4$, with a sharp decrease and no activity at $\mathrm{pH} 7$ and 8, respectively. Previous studies also affirmed that there is a decline in laccase activity as the $\mathrm{pH}$ tends towards neutral and alkaline values (Forootanfar, 2011; $\mathrm{Xu}, 2015)$. The optimum $\mathrm{pH}$ of 4 determined herein for 
laccase from $P$. tuber-regium - Pt30 is comparable to that reported for laccase obtained from Fomes fomentarius (Neifar et al., 2010), P. eryngii, and another Pleurotus sp. (pH 4.5) (More et al., 2011). However, P. ferulae laccase was reported to have the optimum activity at a more acidic $\mathrm{pH}$ (3) than that reported in this study (Ding et al, 2014), and more recently, $\mathrm{pH} 2.6$ was reported as optimal for laccase from Trametes sp. by Wang et al. (2018). For laccase from Tricholoma matsutake, $\mathrm{Xu}$ et al. (2015) reported a less acidic optimum pH (5) than that indicated for laccase in this study.

The optimum temperature of the purified laccase of P. tuber-regium - Pt30 was determined to be $60^{\circ} \mathrm{C}$. In previous studies, fungal laccases were reported to have optimal temperatures ranging from $50^{\circ} \mathrm{C}$ ( Hu et al., 2011; Sharma et al., 2015) to $60^{\circ} \mathrm{C}$ (Neifar et al., 2010; Xu et al., 2015) and $70^{\circ} \mathrm{C}$ (Kiiskinen et al., 2002; D’Souza-Ticlo et al., 2009). Laccase from $P$. tuber-regium - Pt30 had a low $K_{m}$ value $\left(7.82 \times 10^{-5} \mathrm{mM}\right)$ and a high $V_{\text {max }}$ value $(2.9$ $\times 10^{-5} \mathrm{mM}$ ) with ABTS as a substrate. With catechol and guaiacol, the $K_{m}$ values were 6.456 and $32.39 \mathrm{mM}$ respectively while the $V_{\max }$ values were 1.349 and $12.5 \mathrm{mM}$, respectively. Previous observations have shown that the lower the $K_{m}$ value, the higher the affinity of the enzyme for the substrate (Razak and Annuar, 2014). Moreover, the higher the $V_{\max }$, the smaller the quantity of enzyme necessary to convert a substrate into a product (Noreen et al., 2016). In comparison to other fungal laccases, laccases from Sclerotium rolfsii and Pleurotus sp were reported to have a $K_{m}$ of 0.087 and $250 \mathrm{mM}$, respectively, using ABTS as a substrate (Ryan et al., 2003; More et al., 2011).

Like most industrial effluents, textile dye wastewater usually contains high amounts of different metal ions ( $\mathrm{Lu}$ et al., 2012; Mtibaa et al., 2018), and laccases, in real bioremediation applications, are inactivated in the presence of these metals (Xu et al., 2018). Therefore, enzymes used for biodegradation of toxic industrial effluents are desired to function effectively in the presence of various metal ions. In this study, $P$. tuber-regium laccase was resistant to inhibition by all the tested metal ions including, $\mathrm{K}^{+}, \mathrm{Ca}^{2+}, \mathrm{Ba}^{2+}, \mathrm{Hg}^{2+}$, and $\mathrm{Mn}^{+}$. Infact, it is surprising that the presence of $\mathrm{Ca}^{2+}, \mathrm{Ba}^{2+}, \mathrm{Hg}^{2+}, \mathrm{Na}^{+}$and $\mathrm{Mn}^{+}$enhanced the performance of the laccase understudy. A similar observation was made for laccase from P. ferulae (Ding, et al., 2014) while More et al. (2011) reported that the activity of laccase from Pleurotus sp was notably inhibited by metal ions. In contrast to $P$. tuber-regium laccase, the activity of laccase from other species has been reported to be inhibited by $\mathrm{Hg}^{2+}$ in previous studies (Bagewadi et al., 2017; Mtibaa et al., 2018; $\mathrm{Xu}$ et al., 2018) in addition to $\mathrm{K}^{+}$and $\mathrm{Na}^{+}$ions ( $\mathrm{Lu}$ et al., 2012; Atalla et al., 2013). This suggests that $P$. tuber-regium laccase has desirable qualities for industrial applications. Among the tested inhibitors, the activity of laccase from Pt30 mutant was strongly inhibited by sodium azide, and only slightly by EDTA, which confirms the previous observations made by other authors (Baldrian, 2006; Lu, et al., 2007; Forootanfar, et al., 2011).

The decolorization of trypan blue and Congo red dyes were noted in both the solid and liquid media. This suggests that the crude laccase produced in the solid media was as effective as the laccase purified from the liquid media, and thus could save the cost of purification in the bioremediation applications. On the PDA plates supplemented with $0.02 \%$ Congo red dye, it was observed that the dye was biosorbed by the fungi mycelia with the mycelia appearing reddish, while a colorless zone was noticed around the mycelia (Fig. 6). On the other hand, the trypan blue dye was not biosorbed, but was completely metabolized and biodegraded by this fungus probably through the secretion of intracellular laccase (Fig. 6). It was also observed that the trypan blue dye was decolourized faster and better (65\%) than the Congo red dye (28.85\%) in the liquid media after $4 \mathrm{~h}$ of incubation. A similar percentage of decolourization of trypan blue dye was reported for a commercial laccase (62\%) (Razak and Annuar, 2014), while $42 \%$ and $25 \%$ have been reported for laccase from Daedalea quercina and a marine fungus respectively (Baldrian., 2004; D'Souza et al., 2006). It has been established in a previous study that fungal biomass system and purified laccase could be applied in bio-decolourization processes (Razak and Annuar, 2014). The use of the fungal biomass system implies the removal of dyes through their adsorption to the fungi mycelia or intracellular secretion of laccase which then aids in dye biodegradation. However, a free laccase system suggests the separation of laccase from the organism producing it, followed by subsequent purification procedures. The fungus $P$. tuber-regium decolorizes Congo red dye through extracellular secretion of laccase and biosorption of the dye to the biomass. Thus, it is clear from this study that $P$. tuber-regium produces both intracellular and extracellular laccase. 


\section{Conclusions}

In Conclusion, $P$. tuber-regium is a unique fungus, the only sclerotium-forming species of the genus $\mathrm{Pleu}$ rotus. It is edible, has medicinal value and produces laccase that can be effectively used for decolourization processes in textile industries, detergent-producing industries and other related industries. Since this fungus is an edible mushroom, it can also find applications in the food industry for color modification. A further study should be carried out aiming at the bio-catalytic applications of laccase and other industrially relevant enzymes obtained from this fungus.

\section{Acknowledgments}

The authors are grateful to Prof A. Lateef (LAUTECH, Ogbomoso) for critically reading the manuscript, Dr. Leo Ehigie (LAUTECH, Ogbomoso) for his technical advice, and Dr. Ralph Okonji (Obafemi Awolowo University, Ife, Nigeria) for granting permission to make use of his laboratory.

\section{References}

Agrawal K., Chaturvedi V., Verma P. (2018) Fungal laccase discovered but yet undiscovered. Bioresour. Bioprocess 5(1): 4 .

Atalla M.M., Zeinab H.K., Eman R.H., Amani A.Y., Abeer A.A. (2013) Characterization and kinetic properties of the purified Trematosphaeria mangrovei laccase enzyme. Saudi J. Biol. Sci. 20(4): 373-381.

Bagewadi Z.K., Mulla S.I., Ninnekar H.Z. (2017) Purification and immobilization of laccase from Trichoderma harzianum strain HZN10 and its application in dye decolorization. J. Genet. Eng. Biotechnol. 15(1): 139-150.

Baker W.L., Sabapathy K., Vibat M., Lonergan G. (1996) Laccase catalyzes formation of an indamine dye between 3 methyl-2-benzothiazolinone hydrazone and 3-dimethylaminobenzoic acid. Enzyme Microb. Technol. 18: 90-94.

Baldrian P. (2004) Purification and characterization of laccase from the white-rot fungus Daedalea quercina and decolorization of synthetic dyes by the enzyme. Appl. Microbiol. Biotechnol. 63: 560-63.

Baldrian P. (2006) Fungal laccases - occurrence and properties. FEMS Microbiol. Rev. 30: 215-242.

Bamigboye C.O., Oloke J.K., Dames J.F. (2016) Biological activity of extracellular and intracellular polysaccharides from Pleurotus tuber-regium hybrid and mutant strains. J. Food Nutr. Res. 4(7): 422-428.

Bamigboye C.O., Oloke J.K., Burton M., Dames J.F. Lateef A. (2019) Process optimization for production of biomass and exopolysaccharide by king tuber oyster mushroom, Pleurotus tuber-regium (Agaricomycetes) for biotechnological applications. Int. J. Med. Mush. 21(4): 311-322.

Behrens C.J., Linke D., Allister A.B., Zelena K., Berger R.G. (2017) Variants of PpuLcc, a multi-dye decolorizing laccase from Pleurotus pulmonarius expressed in Pichia pastoris. Protein Expr. Purif., 137: 34-42.

Bradford M.M. (1976) A rapid and sensitive method for the quantitation of microgram quantities of protein utilizing the principle of protein-dye binding. Anal. Biochem, 72: 248-254.

Cai X., Davis E.J., Ballif J., Liang M., Bushman E., Haroldsen V., Torabinejad J., Wu Y. (2006) Mutant identification and characterization of the laccase gene family in Arabidopsis. J. Exp. Bot., 57(11): 2563-2569.

Ding Z., Chen Y., Xu Z., Peng L., Xu G., Gu Z., Zhang L., Shi G., Zhang K. (2014) Production and characterization of laccase from Pleurotus ferulae in submerged fermentation. Ann. Microbiol. 64: 121-129.

D’Souza D.T., Tiwari R., Sah A.K., Raghukumar C. (2006) Enhanced production of laccase by a marine fungus during treatment of colored effluents and synthetic dyes. Enzym. Microb. Technol. 38(3-4): 504-511.

D'Souza-Ticlo D., Sharma D. Raghukumar C. (2009) A thermostable metal-tolerant laccase with bioremediation potential from a marine-derived fungus. Mar. Biotechnol. 11(6): 725-737.

El-Batal A.I., Elkenawy N.M., Yassin A.S., Amin M.A. (2015) Laccase production by Pleurotus ostreatus and its application in synthesis of gold nanoparticles. Biotechnol. Rep. 5: 31-39.

E1 Monssef R.A.A., Hassan E.A., Ramadan E.M. (2016) Production of laccase enzyme for their potential application to decolorize fungal pigments on aging paper and parchment. Ann. Agric. Sci. 61(1): 145-154.

Forootanfar H., Faramarzi M.A., Shahverdi A.R., Yazdi M.T. (2011) Purification and biochemical characterization of extracellular laccase from the ascomycete Paraconiothyrium variabile. Biores. Technol. 102: 1808-1814.

Fokina O., Eipper J., Kerzenmacher S., Fischer R. (2016) Selective natural induction of laccases in Pleurotus sajor-caju, suitable for application at a biofuel cell cathode at neutral pH. Biores. Technol. 218: 455-462.

Fritz-Langhals E., Kunath B. (1998) Synthesis of aromatic aldehydes by laccase mediator assisted oxidation. Tetrahedron Lett. 39: 5955-5956.

Geng A., Wu J., Xie R.R., Li X., Chang F.X., Sun J.Z. (2018) Characterization of a laccase from a wood feeding termite, Coptotermes formosanus. Insect sci. 25(2): 251-258.

Henson J.M.., Butler M.J. Day A.W. (1999) The dark side of the mycelium: melanins of phytopathogenic fungi. Ann. Rev. Phytopathol. 37: 447-471.

Isikhuemhen O.S. Nerud F. (1999) Preliminary studies on the ligninolytic enzymes produced by the tropical fungus P. tuber-regium. A. van Leeuwenhoek 75: 257-260.

Jebapariya G.R., Gnanadoss J.J. (2014) Screening and molecular characterization of white rot fungi capable of laccase production and dye decolourization. Int. J. Life Sci. Pharma Res. 2(2): 12-20.

Kiiskinen L.-L., Viikari L., Kruus K. (2002) Purification and characterisation of a novel laccase from the ascomycete 
Melanocarpus albomyces. Appl. Microbiol. Biotechnol. 59: 198-204

Kiiskinen L.-L., Ratto M., Kruus K. (2004) Screening for novel-producing microbes. J. Appl. Microbiol. 97: 640-646.

Kuddus M., Joseph B., Ramteke P.W. (2013) Production of laccase from newly isolated Pseudomonas putida and its application in bioremediation of synthetic dyes and industrial effluents. Biocatal. Agric. Biotechnol. 2: 333-338.

Kunamneni A., Ballesteros A., Plou F.J., Alcalde M. (2007) Fungal laccase - a versatile enzyme for biotechnological applications. Communicating Current Research and Educational Topics and Trends in Applied Microbiology. Spain: Formatex publishers: 233-244.

Kunamneni A., Camarero S., García-Burgos C., Plou F.J., Ballesteros A., Alcalde M. (2008) Engineering and applications of fungal laccases for organic synthesis. Microb. Cell Fact. 7(1): 32.

Lineweaver H., Burk D.D. (1934) The determination of enzyme dissociation constants. J. Am. Chem. Soc. 56: 658-663.

Loi M., Fanelli F., Cimmarusti M.T., Mirabelli V., Haidukowski M., Logrieco A.F., Caliandro R., Mule G. (2018) In vitro single and combined mycotoxins degradation by Ery4 laccase from Pleurotus eryngii and redox mediators. Food Control. 90: 401-406.

Lu C., Cao L., Liu R., Lei Y., Ding G. (2012) Effect of common metal ions on the rate of degradation of 4-nitrophenol by a laccase-Cu2+ synergistic system. J. Environ. Manage. 113: $1-6$.

Lu L., Zhao M., Zhang B., Yu S., Bian X., Wang W., Wang Y. (2007) Purification and characterization of laccase from Pycnoporus sanguineus and decolorization of an anthraquinone dye by the enzyme. Appl. Microbiol. Biotechnol. 74: $1232-1239$

Martani F., Beltrametti F., Porro D., Branduardi P., Lotti M. (2017) The importance of fermentative conditions for the biotechnological production of lignin modifying enzymes from white-rot fungi. FEMS Microbiol. Lett. 364(13), fnx134.

Marques de Souza C.G., Peralta R.M. (2003) Purification and characterization of the main laccase produced by the white rot fungus Pleurotus pulmonarius on wheat bran solid state medium. J. Basic Microbiol. 43(4): 278-286.

More S.S., Renuka P.S., Pruthvi K., Swetha M., Malini S., Veena S.M. (2011) Isolation, purification, and characterization of fungal laccase from Pleurotus sp. Enzyme Res. 3: $5-14$.

Mtibaà R., Barriuso J., de Eugenio L., Aranda E., Belbahri L., Nasri M., Martínez M.J., Mechichi T. (2018) Purification and characterization of a fungal laccase from the ascomycete Thielavia sp. and its role in the decolorization of a recalcitrant dye. Int. J. Biol. Macromol. 120: 1744-1751.

Nagai M., Kawata M., Watanabe H., Ogawa M., Saito K., Takesawa T., Kanda K., Sato T. (2003) Important role of fungal intracellular laccase for melanin synthesis: purification and characterization of an intracellular laccase from Lentinula edodes fruit bodies. Microbiol. 149(9): 2455-2462.
Ncanana S., Baratto L., Roncaglia L., Riva S., Burton S.G. (2007) Laccase-mediated oxidation of totarol. Adv. Synth. Catal. 349: 1507-1513.

Neifar M., Jaouani A., Ellouze-Ghorbel R., Ellouze-Chaabouni S. (2010) Purification, characterization and decolourization ability of Fomes fomentarius laccase produced in solid medium. J. Mol. Catal. B Enzym. 64: 68-74.

Niladevi K.N., Prema P. (2008) Effect of inducers and process parameters on laccase production by Streptomyces psammoticus and its application in dye decolourization. Biores. Technol. 99: 4583-4589.

Noreen S., Asgher M., Hussain F., Iqbal A. (2016) Perfomance improvement of calcium-alginate bead cross-linked laccase from Trametes versicolor IBL-04. Biores. 11(1): 558-572.

Okhuoya J.A., Okogbo F.O. (1990) Induction of edible sclerotia of Pleurotus tuber-regium (Fr) Sing. in the laboratory. Ann. Appl. Biol. 117: 295-298.

Othman A.M., Elshafei A.M., Hassan M.M., Haroun B.M., Elsayed M.A., Farrag A.A. (2014) Purification, biochemical characterization and applications of Pleurotus ostreatus ARC280 laccase. Brit. Microbiol. Res. J. 4(12): 1418-1439.

Pandey R.K., Tewari S., Tewari L. (2018) Lignolytic mushroom Lenzites elegans WDP2: Laccase production, characterization, and bioremediation of synthetic dyes. Ecotoxicol. Environ. Saf. 158: 50-58.

Patel S.J., Onkarappa R., Gurumurthy S.B., Shobha K.S. (2011) Production and isolation of laccases from cellulytic fungi. Dev. Microbiol. Mol Biol. 2: 93-99.

Prajapati H.V., Minocheherhomji F.P. (2018) Laccase - a wonder molecule: a review of its properties and applications. Int. J. Pure App. Biosci. 6(1): 766-773.

Ramírez-Cavazos L.I., Junghanns C., Ornelas-Soto N., Cárdenas-Chávez D.L., Hernández-Luna C., Demarche P., Enaud E., García-Morales R., Agathos S.N. Parra R. (2014) Purification and characterization of two thermostable laccases from Pycnoporus sanguineus and potential role in degradation of endocrine disrupting chemicals. J. Mol. Catal., B Enzym. 108: 32-42.

Razak N.N.A., Annuar M.S.M. (2014) Thermokinetic comparison of trypan blue decolorization by free laccase and fungal biomass. Appl. Biochem. Biotechnol. 172: 2932-2944.

Ryan S., Schnitzhofer W., Tzanov T., Cavaco-Paulo A., Gübitz G.M. (2003) An acid-stable laccase from Sclerotium rolfsii with potential for wool dye decolourization. Enzym. Microb. Technol. 33: 766-774.

Salmones D., Mata G. (2015) Laccase production by Pleurotus djamor in agar media and during cultivation on wheat straw. Rev. Mex. Micol. 42: 17-3.

Schwienheer C., Prinz A., Zeiner T., Merz J. (2015) Separation of active laccases from Pleurotus sapidus culture supernatant using aqueous two-phase systems in centrifugal partition chromatography. J. Chromatogr. B Biomed. Sci. Appl. 1002: 1-7.

Sharma A., Jain K.K., Jain A., Kidwai M., Kuhad R.C. (2018) Bifunctional in vivo role of laccase exploited in multiple biotechnological applications. Appl. Microbiol. Biotechnol. 102(24): 10327-10343. 
Sharma D., Goel G., Sud A., Chauhan R.S. (2015) A novel laccase from newly isolated Cotylidia pannosa and its application in decolorization of synthetic dyes. Biocatal. Agric. Biotechnol.http://dx.doi.org/10.1016/j.bcab.2015.07.008i.

Verma A., Dhiman K., Shirkot P. (2016) Hyper-production of laccase by Pseudomonas putida LUA15.1 through mutagenesis. J. Microbiol. Exp. 3(1): 00080.

Vilgalys R., Moncalvo J.M., Liou S.R., Volovsek M. (1996) Recent advances in molecular systematics of the genus Pleurotus. [in:] Royse. University Park, PA (USA), Pennsylvania State University. World Society for Mushroom Biology and Mushroom Products: 91-101.

Wang H., Peng L., Ding Z., Wu J., Shi G. (2015) Stimulated laccase production of Pleurotus ferulae JM301 fungus by Rhodotorula mucilaginosa yeast in co-culture. Process Biochem. 50(6): 901-905.

Wang S.N., Chen Q.J., Zhu M.J., Xue F.Y., Li W.C., Zhao T.J., Li G.D., Zhang G.Q. (2018) An extracellular yellow laccase from white rot fungus Trametes sp. F1635 and its mediator systems for dye decolorization. Biochimie 148: 46-54.

Wang S.S., Ning Y.J., Wang S.N., Zhang J., Zhang G.Q., Chen Q.J. (2017) Purification, characterization, and cloning of an extracellular laccase with potent dye decolorizing ability from white rot fungus Cerrena unicolor GSM-01. Int. J. Biol. Macromol. 95: 920-927.

Wang Q., Qian Y., Ma Y., Zhu C. (2018) A preliminary study on the newly isolated high laccase-producing fungi: screening, strain characteristics and induction of laccase production. Open Life Sci. 13(1): 463-469.
Xu L., Zhu M., Chen X., Wang H., Zhang H. (2015) A novel laccase from fresh fruiting bodies of the wild medicinal mushroom Tricholoma matsutake. Acta Biochim. Pol. 62: $35-40$.

Xu X., Huang X., Liu D., Lin J., Ye X., Yang J. (2018) Inhibition of metal ions on Cerrena sp. laccase: Kinetic, decolorization and fluorescence studies. J. Taiwan Inst. Chem. E 84: $1-10$.

Yadav M., Bista G., Maharjan R., Poudyal P., Mainali M., Sreerama L., Joshi J. (2019) Secretory laccase from pestalotiopsis species CDBT-F-G1 fungal strain isolated from high altitude: optimization of its production and characterization. Appl. Sci. 9(2): 340. DOI: 10.3390/app9020340.

Yatsu J., Asano T. (2009) Cuticle laccase of the silkworm, Bombyx mori: purification, gene identification and presence of its inactive precursor in the cuticle. Insect Biochem. Mol. Biol. 39(4): 254-262.

Zhang G.-Q., Wang Y.-F., Zhang X.-Q., Ng T.B., Wang H.-X. (2010) Purification and characterization of a novel laccase from the edible mushroom Clitocybe maxima. Process Biochem. 45: 627-633.

Zheng F., An Q., Meng G., Wu X.J., Dai Y.C., Si J., Cui B.K. (2017) A novel laccase from white rot fungus Trametes orientalis: Purification, characterization, and application. Int. J. Biol. Macromol. 102: 758-770. 